\title{
Online Firms' Management of Customer Risk and Risk Perceptions in Ghana: Evidence from Selected Online Firms
}

\author{
Kannyiri Banyen \\ University for Development Studies \\ School of Business and Law \\ Department of Banking and Finance \\ Wa, Ghana
}

\author{
Yaw Afriyie \\ University for Development Studies \\ School of Business and Law \\ Department of Accounting \\ Wa, Ghana
}

\author{
Samuel Owusu Amponsah \\ University for Development Studies \\ School of Business and Law \\ Department of Procurement and \\ Marketing \\ Wa, Ghana
}

\begin{abstract}
In developing countries like Ghana, where Information Technology (IT) usage is still developing widespread use, understanding the risk and perceptions of online business is not only essential for improving purchase likelihood for customers and individual firms' products but critical for the general growth and development of E-commerce in the country. This study examines the risk perceptions of customers of online firms in Ghana and evaluates strategies adopted by online firms to address these risks perceptions in the country. The study uses primary data from a field survey of 43 workers and 78 customers of 13 online firms in Ghana where the empirical investigation reveals that the negative risk perceptions of online customers emanate from various factors including 'technological illiteracy', poor safety and privacy policies, prior security breaches, poor electronic payment platforms, low awareness among others. The study also finds that despite the adoption of various strategies to eradicate these perceptions and improve traffic to online business portals, these perceptions are still in existence and continue to persist. The evidences also point to the fact that online firms in Ghana need to adopt better and more secure servers and create public awareness of their level of security in order to stimulate customer confidence in online business safety.
\end{abstract}

\section{Keywords}

Information and Communication Technology (ICT), Internet Security Breaches, Transmission Control Protocol, Open System Interconnection, Denial of Service (DoS), Automated Teller Machine

\section{INTRODUCTION}

The last three decades have witnessed a rapid increase in the use of information communication technology globally, with web-based businesses accounting for high chunks of the GDP of many countries [1]-[2]. According to Karagozoglu and Lindell [3], the electronic business industry is one of the most crucial sectors needed to propel the development agenda of every nation. Since the emergence of the internet and a growing adoption of IT products and platforms by businesses and their customers, e-commerce has become a key source of building competitive advantage among businesses. Ecommerce also serves as a means of reaching a wider market, reduces selling and distribution cost and increasing corporate profits [4]. However, despite the heralded benefits of ecommerce to global development, there is growing concern among stakeholders about a number of risk factors [5] - [6]. According to Horrigan [7], about fifty-eight percent of all internet users have some concerns about online shopping and this often results in a high abandonment rate for most online transactions. Over the years, since the discovery of the first computer virus, several security concerns have been raised by both businesses and clients using IT products and platforms. A number of studies have been conducted on how to deal with these security issues and online companies often take several key measures to reduce the risk exposure of their firms and clients. However, there is a general paucity of both theoretical and empirical literature on how to manage the perceived risk exposures of online firms as opposed to the abundance of studies on actual risk exposure.

According to Maziriri and Chuchu [8], the dilemma faced by customers shopping online regarding the quality of information on online firms' websites, firm reputation, privacy and cyber security has become a global concern, especially for stakeholders of the online business industry [9] - [10]. The growing lack of customers trust for online businesses has major repercussions for the growth and development of e-commerce [11] - [13]. This is even direr in nascent economies, where customer safety legislations are either inadequate or non-existent, coupled with poor monitoring systems and other negative socio-cultural factors. To the best of the researcher's knowledge there are no prior empirical studies on the strategies used by online firms to reduce the risk perceptions of their clients in Ghana. This paper therefore examines the perceived risks of online business customers and evaluates the strategies adopted by online firms to manage these perceived risks of clients and how they affect their clients purchasing behavior. This paper provides a broad understanding of perception reduction strategies in nascent markets with the view of assuring clients of their safety and improving e-commerce adoption in nascent economies.

\section{OBJECTIVE OF THIS STUDY}

This study largely seeks to examine the perceived risks of customers of online firms in Ghana and evaluate the strategies used by these firms to manage these risks to ensure safer online commerce in the country.

\section{METHODOLOGY OF THE STUDY}

In this study, the researchers applied survey research methods to collect Primary data from Workers, Customers and Online firms and the study further adopted quantitative research technique. The data collected for the research have been analysed using SPSS V22. Microsoft Office Excel 2016 was also employed for the preparation of charts. The justification for the methods used in this research is based on the fact that "it allows researchers to study the effects of the dependent variables and its relationship on the independent variables [15]. 


\section{RESULTS, ANALYSIS AND DISCUSSION}

This section discusses the analysis of the data collected based on firsthand information. This study considered a total of 148 respondents which comprised of 78 customers, 43 workers and 13 online firms. Since gender has implications for human behavior, knowledge of participants' gender was sought. This is because many studies have revealed that males and females may have similar shopping motives, but their shopping habits may not necessarily be the same. Table 1 indicates the cross tabulation of respondents' based on gender with their respondent categories to bring out a more holistic picture about the study sample.

Table 1: Gender of Respondents

\begin{tabular}{|c|c|c|c|c|}
\hline \multicolumn{2}{|c|}{ Respondent Category } & \multicolumn{2}{|c|}{ Gender } & \multirow[t]{2}{*}{ Totals } \\
\hline & & Male & Female & \\
\hline \multirow[t]{2}{*}{ Workers } & Frequency & 43 & 19 & 62 \\
\hline & Percentage & $69.35 \%$ & $30.65 \%$ & $100 \%$ \\
\hline \multirow[t]{2}{*}{ Customers } & Frequency & 32 & 27 & 59 \\
\hline & Percentage & $54.24 \%$ & $45.76 \%$ & $100 \%$ \\
\hline \multirow[t]{2}{*}{ Totals } & Frequency & 75 & 46 & 121 \\
\hline & Percentage & $61.98 \%$ & $31.02 \%$ & $100 \%$ \\
\hline
\end{tabular}

From Table 1, most of the respondents are males which indicates that most males in Ghana shop online which has the highest percentage of 69.35 with the females showing a percentage of 30.65 .

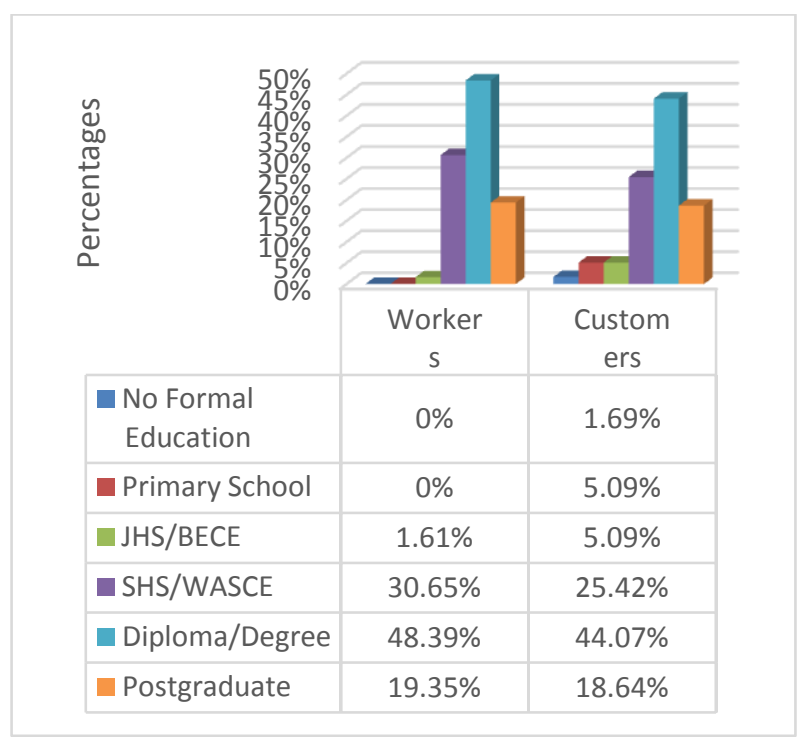

Figure 1: Educational Level of Respondents

The study sought to find out the educational level of respondents to understand how they appreciate online business. Figure 1 shows that most online firms in Ghana have some form of Post-secondary or tertiary education. From the figure, it is evident that $48.39 \%$ of the respondents have Diploma or First degree, whilst an additional 19.35\% have a Postgraduate degree, with a $30.65 \%$ indicated that they have had High School Education. However, a least percentage of $1.61 \%$ from the Survey indicated that they only had Basic Education.

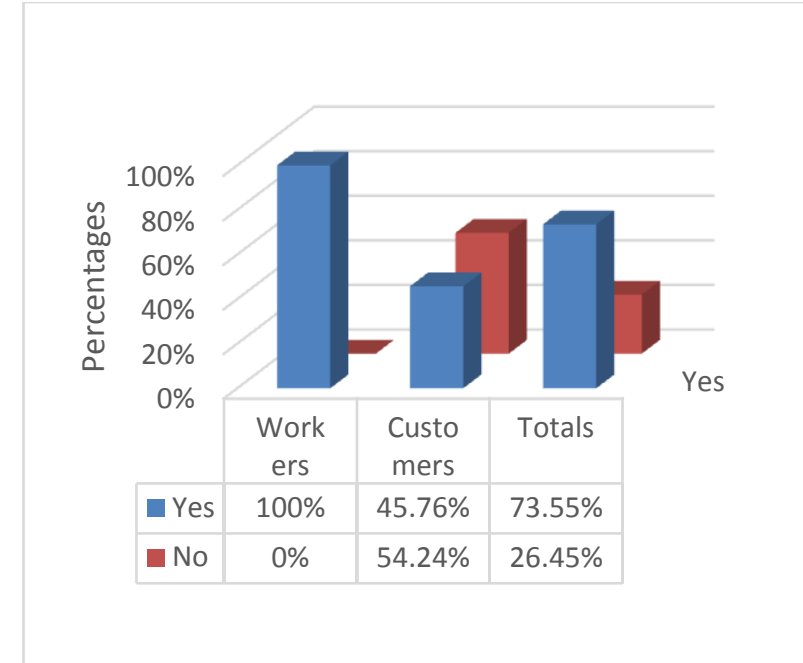

Figure 2: Respondents Literacy in Information Technology

The study further probed the literacy level of respondents with respect to Information Technology (IT) literacy. The responses as shown in Figure 4.2 reveals that most customers $(54.24 \%)$ of online firms in Ghana have no literacy in information communication technology. This is because whilst about $73.55 \%$ of all respondents indicated they had some literacy in IT, most customers $(54.24 \%)$ do not possess any IT literacy.

However, Figure 2 reveals that all the online firms' workers have some level of IT literacy. This suggest that most people shopping online are naïve about the workings of the internet and may not fully understand the level of security or risk exposure involved in transacting online. There is therefore a high probability of forming wrong perceptions about these issues and could explain the level of consumer risk perception in the country.

Figure 3 shows that most customers of online firms in Ghana have very short online shopping experience. This is because about 39 percent of the customers sampled indicated they have been shopping online for 1 year or less. An additional 27 percent indicated they have only been shopping online for at between 1 to 2 years.

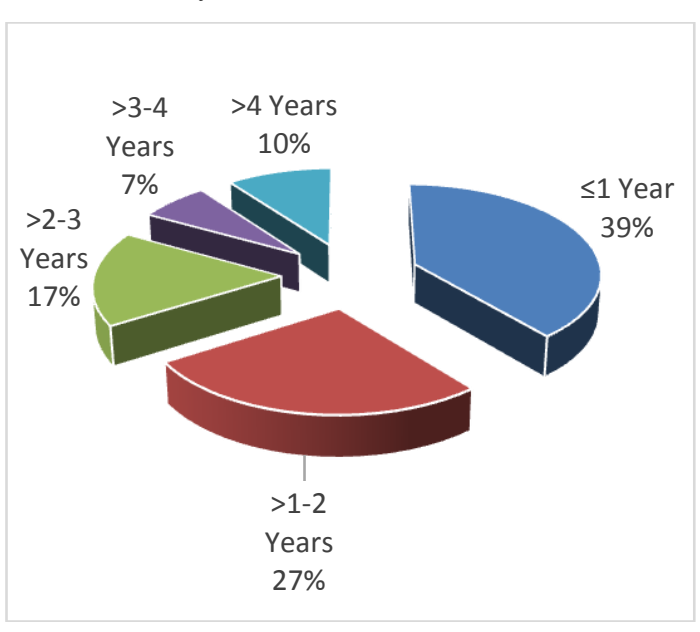

Figure 3: Online Shopping Experience

Cumulatively, this makes up a majority of the customers sampled. This finding is in line with findings in previous studies such as [13] who find that online shopping experience 
is adversely related with negative consumer risk perception across all product categories. This means that online business customers who have been shopping online for some time will have a lower risk perception than those with little to no experience shopping online. This may be due a better understanding of the risk and return of shopping online gathered from previous experiences. This is also expected to influence their buying behavior positively [14]. The risk perceptions of online firm customers in Ghana are therefore expected to be high-negative due to the high numbers of customers with little online shopping experience. Several studies reviewed in the literature have suggested that the number of times or duration of a customer's experience with a shopping method has a significant effect on their perceived risk related to that method. The study therefore conjectures that the longer a customer of an online firm transacts business online, the lower their perceived risk will be.

Table 2 shows a cross tabulation of the responses from customers only about their level of online shopping experience and the various types of risk perceived by only customers. The results show that online shopping experience is inversely related to consumer risk perceptions. This is because we find that the dominance of risk perceptions reduces with increasing years of online shopping experience.

Respondents were also asked to indicate any other factors that might be influencing their risk perceptions about shopping online. Their responses are displayed on Table 3. The Table further reveals that ignorance about online security is a key factor contributing to the risk perceptions of online consumers in Ghana. This is because about $88.43 \%$ of the respondents identified ignorance of cyber security issues as the key factor responsible for the risk perceptions of online consumers. Besides, $75.21 \%$ of the respondents identified prior exposure to risk events as a major contributory factor. This was related to either personal experience or that of a known person.

Table 3 also shows that $56.2 \%$ of the respondents revealed that lack of warranties and the possibility of returning defective commodities, is a major factor accounting for the level of risk perceived by online consumers. This is closely followed by poor safety and privacy policies $(52.89 \%)$ and lack of pre-purchase assistance (50.41\%).

Table 3: Factors Responsible for Consumer Risk Perceptions

\begin{tabular}{|l|c|c|}
\hline Factors & Frequency (out of 121) & Percentage(\%) \\
\hline $\begin{array}{l}\text { Prior Exposure to } \\
\text { Risk Event }\end{array}$ & 91 & 75.21 \\
\hline $\begin{array}{l}\text { Ignorance About } \\
\text { Cyber Security }\end{array}$ & 107 & 88.43 \\
\hline No Warranties & 68 & 56.20 \\
\hline $\begin{array}{l}\text { Lack of Pre- } \\
\text { purchase } \\
\text { Assistance }\end{array}$ & 61 & 50.41 \\
\hline $\begin{array}{l}\text { Poor safety and } \\
\text { privacy policies }\end{array}$ & 64 & 52.89 \\
\hline
\end{tabular}

Figure 4 shows that the presence of perceived financial risk drastically reduces the likelihood that a consumer will purchase goods offered online. Respondents representing $40.49 \%$ indicated that they are unlikely to make a purchase from an online firm if they perceive financial risk exposure whiles $25.62 \%$ indicated that they are very unlikely to make the purchase. Therefore, a cumulative percentage of $66.11 \%$ of all respondents are likely to refuse purchasing from an online firm if they perceive they are exposed to financial risk. Also, social risk seems to be very important to online consumers in Ghana.

Table 2: Prior Online Experience and Perceived Risk

\begin{tabular}{|c|c|c|c|c|c|c|c|c|c|c|c|c|}
\hline \multirow{2}{*}{$\begin{array}{l}\text { Online } \quad \text { Experience } \\
\text { Time }\end{array}$} & \multicolumn{2}{|c|}{ Performance } & \multicolumn{2}{|c|}{ Financial } & \multicolumn{2}{|c|}{ Time } & \multicolumn{2}{|c|}{ Physical } & \multicolumn{2}{|c|}{ Psychological } & \multicolumn{2}{|c|}{ Social } \\
\hline & $\mathbf{Y}$ & $\mathbf{N}$ & $\mathbf{Y}$ & $\mathbf{N}$ & $\mathbf{Y}$ & $\mathbf{N}$ & $\mathbf{Y}$ & $\mathbf{N}$ & $\mathbf{Y}$ & $\mathbf{N}$ & $\mathbf{Y}$ & $\mathbf{N}$ \\
\hline$\leq 1$ Year & 15 & 8 & 18 & 5 & 13 & 10 & 12 & 11 & 14 & 9 & 16 & 7 \\
\hline$>1-2$ Years & 9 & 7 & 12 & 4 & 9 & 7 & 8 & 8 & 10 & 6 & 11 & 5 \\
\hline$>2-3$ Years & 6 & 4 & 7 & 3 & 4 & 6 & 3 & 7 & 5 & 5 & 4 & 6 \\
\hline$>3-4$ Years & 1 & 3 & 2 & 2 & 0 & 4 & 1 & 3 & 1 & 3 & 2 & 2 \\
\hline$>4$ Years & 1 & 5 & 2 & 4 & 0 & 6 & 0 & 6 & 1 & 5 & 2 & 4 \\
\hline Total & 32 & 27 & 41 & 18 & 26 & 33 & 24 & 35 & 31 & 28 & 35 & 24 \\
\hline
\end{tabular}

Key: $\mathrm{Y}=\mathrm{Yes}, \mathrm{N}=\mathrm{No}$ 


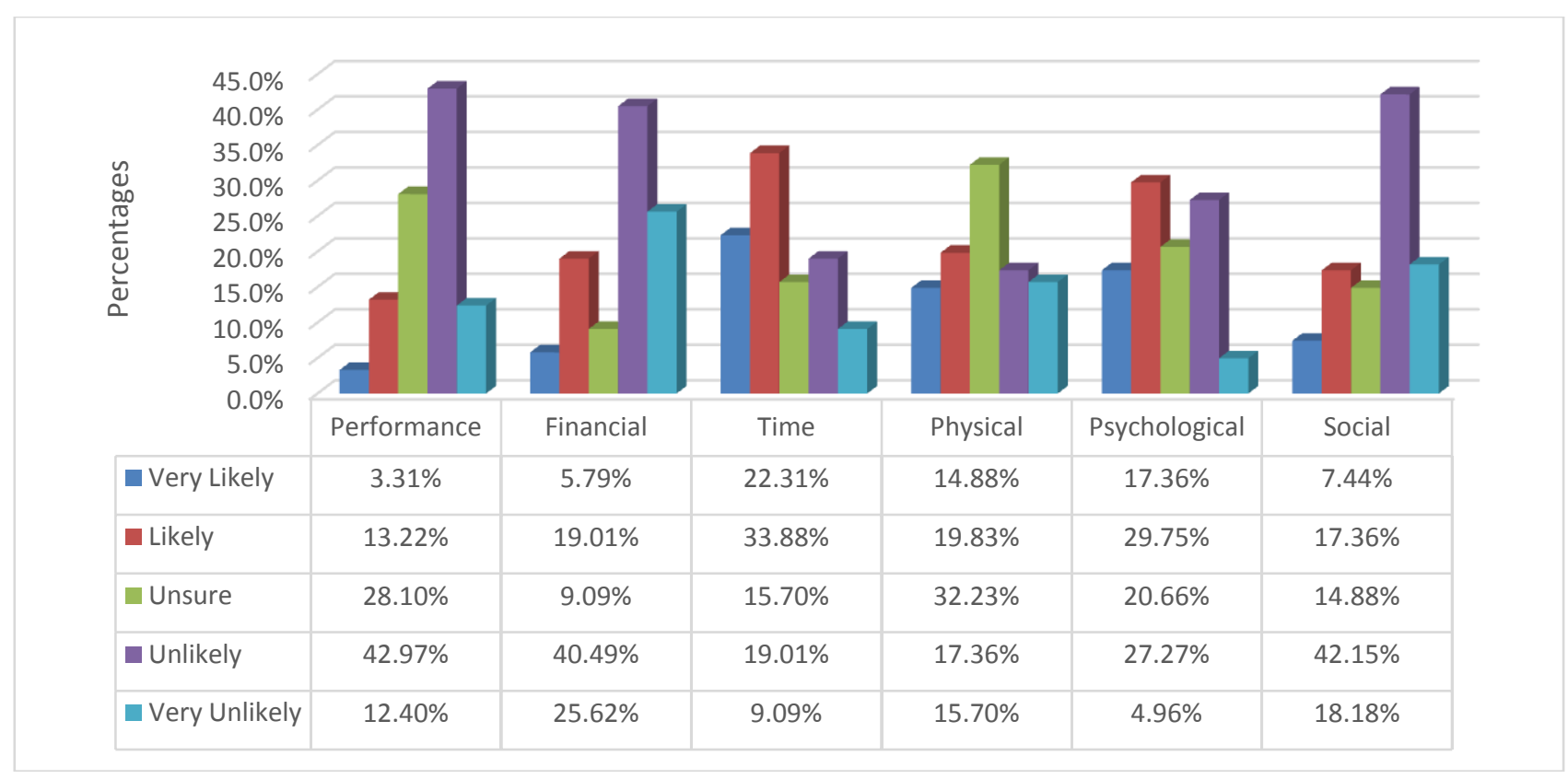

Figure 4: Risk Perception and Purchase Likelihood

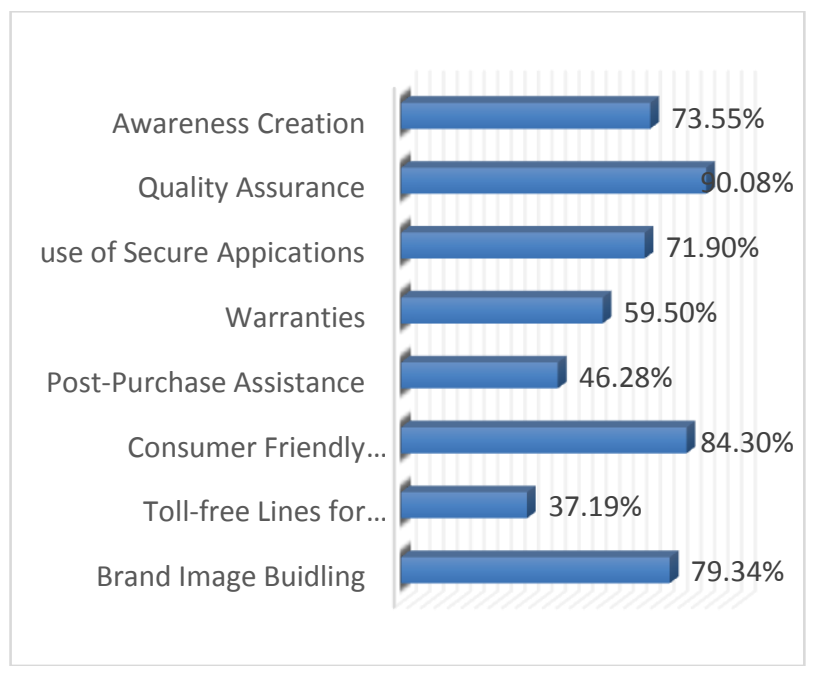

Figure 5: Known Risk Perception of Management Methods Also, about $42.15 \%$ of respondents indicated that online consumers are unlikely to make a purchase in the presence of social risk perception and an additional $18.18 \%$ indicated they are very unlikely to make the purchase. This forms a cumulative of $60.33 \%$ of responses. Similarly, performance risk has a negative effect on purchase likelihood. This is because $42.97 \%$ of the respondents indicated that they are unlikely to purchase online when they feel there is a performance risk to the purchase and an additionally $12.4 \%$ indicated they are very unlikely to make such a purchase. Cumulatively, this makes about $55.37 \%$ of total respondents. Figure 5 reveals that the most common risk perception mitigation strategy adopted by online firms in Ghana was an assurance of the quality of products provided by the firms on their websites. This is because $90.08 \%$ of the respondents indicated that firms often provide some level of assurance about the efficacy and quality of their product offerings. In addition, about $84.3 \%$ of the respondents indicated that online firms also try to ensure that their websites are friendly to promote easier and speedy transactions. This is meant to provide shoppers with some level of comfort and may ease some tension and reduce their levels of anxiety.

Table 3 shows a detailed description of the effectiveness of some perceived risks strategies in the conduct of business online with respect to quality assurance, awareness creation amongst others. Respondents had varying reasons and perceptions to the factors that reduce the customer risk perception of online business.

Table 4: Effectiveness of Perceived Risks Reduction Strategy

\begin{tabular}{|l|l|l|l|l|l|l|}
\hline \multirow{2}{*}{ Perceived Risks Reduction Strategy } & \multicolumn{5}{c|}{ Effectiveness on Customer Risk Perception Reduction } \\
\cline { 3 - 7 } & $\begin{array}{c}\text { Very } \\
\text { Effective }\end{array}$ & Effective & Uncertain & Ineffective & Very Ineffective \\
\hline $\begin{array}{l}\text { Awareness } \\
\text { Creation }\end{array}$ & Frequency & 36 & 31 & 20 & 24 & 10 \\
\cline { 2 - 7 } & Percentage & $29.75 \%$ & $25.62 \%$ & $16.53 \%$ & $19.83 \%$ & $8.26 \%$ \\
\hline $\begin{array}{l}\text { Use of Secure } \\
\text { Application }\end{array}$ & Frequency & 51 & 28 & 19 & 13 & 10 \\
\cline { 2 - 7 } & Percentage & $42.15 \%$ & $23.14 \%$ & $15.71 \%$ & $10.74 \%$ & $8.26 \%$ \\
\hline
\end{tabular}




\begin{tabular}{|c|c|c|c|c|c|c|}
\hline \multirow{2}{*}{$\begin{array}{l}\text { Quality } \\
\text { Assurance }\end{array}$} & Frequency & 23 & 29 & 14 & 25 & 20 \\
\hline & Percentage & $19.01 \%$ & $23.97 \%$ & $11.57 \%$ & $20.66 \%$ & $16.53 \%$ \\
\hline \multirow[t]{2}{*}{ Warranties } & Frequency & 24 & 33 & 21 & 30 & 13 \\
\hline & Percentage & $19.83 \%$ & $27.27 \%$ & $17.36 \%$ & $24.79 \%$ & $10.74 \%$ \\
\hline \multirow{2}{*}{$\begin{array}{l}\text { Post-Purchase } \\
\text { Assistance }\end{array}$} & Frequency & 19 & 27 & 31 & 21 & 13 \\
\hline & Percentage & $15.71 \%$ & $22.31 \%$ & $25.62 \%$ & $17.36 \%$ & $10.74 \%$ \\
\hline \multirow{2}{*}{$\begin{array}{l}\text { Consumer- } \\
\text { Friendly } \\
\text { Websites }\end{array}$} & Frequency & 12 & 28 & 37 & 23 & 11 \\
\hline & Percentage & $9.92 \%$ & $23.14 \%$ & $30.58 \%$ & $19.01 \%$ & $9.09 \%$ \\
\hline \multirow{2}{*}{$\begin{array}{l}\text { Toll-free Lines } \\
\text { for Assistance }\end{array}$} & Frequency & 24 & 32 & 30 & 18 & 17 \\
\hline & Percentage & $19.83 \%$ & $26.45 \%$ & $24.79 \%$ & $14.88 \%$ & $14.05 \%$ \\
\hline \multirow{2}{*}{$\begin{array}{l}\text { Brand Image } \\
\text { Building }\end{array}$} & Frequency & 47 & 38 & 4 & 21 & 11 \\
\hline & Percentage & $38.84 \%$ & $31.41 \%$ & $3.31 \%$ & $17.36 \%$ & $9.09 \%$ \\
\hline \multicolumn{4}{|c|}{$\begin{array}{l}\text { The study finally sought the views of respondents to indicate } \\
\text { whether the presence of the various types of risk perception } \\
\text { reduction strategies will increase the probability or likelihood } \\
\text { that a customer will make a purchase online. The responses } \\
\text { from the questionnaire are displayed in Figure } 6 \text {. The figure } \\
\text { further shows that brand image building has the highest }\end{array}$} & \multicolumn{3}{|c|}{$\begin{array}{l}\text { probability of reducing customer concerns and stimulating a } \\
\text { purchase decision by the consumer. This is because } 42.15 \% \\
\text { of the respondents indicated that it will very likely stimulate a } \\
\text { purchase and } 19.01 \% \text { said it would likely do so. This makes a } \\
\text { total of } 61.16 \% \text { who think that if online firms can build a } \\
\text { unique good image regarding their product and service } \\
\text { offerings, customers are more likely to purchase from them. }\end{array}$} \\
\hline
\end{tabular}

\begin{tabular}{|c|c|c|c|c|c|c|c|c|}
\hline $45.00 \%$ & 1 & & & & & & & \\
\hline $\begin{array}{l}40.00 \% \\
35.00 \%\end{array}$ & & & & & & & & \\
\hline $30.00 \%$ & & & & & & & & \\
\hline $25.00 \%$ & & & & & & & & \\
\hline $20.00 \%$ & & & & & & & & \\
\hline $15.00 \%$ & & & & & & & & \\
\hline $10.00 \%$ & & & & & & & & \\
\hline $5.00 \%$ & & & & & & & & 11 \\
\hline $0.00 \%$ & $\begin{array}{l}\text { Brand } \\
\text { Image } \\
\text { Buidling }\end{array}$ & $\begin{array}{l}\text { Toll-free } \\
\text { Lines }\end{array}$ & $\begin{array}{l}\text { Friendly } \\
\text { Websites }\end{array}$ & $\begin{array}{c}\text { Post- } \\
\text { Purchase } \\
\text { Assistance }\end{array}$ & $\begin{array}{c}\text { Warrantie } \\
\mathrm{s}\end{array}$ & $\begin{array}{c}\text { use of } \\
\text { Secure } \\
\text { Apps }\end{array}$ & $\begin{array}{c}\text { Quality } \\
\text { Assurance }\end{array}$ & $\begin{array}{c}\text { Awareness } \\
\text { Creation }\end{array}$ \\
\hline - Very Likely & $42.15 \%$ & $17.36 \%$ & $7.44 \%$ & $17.36 \%$ & $32.23 \%$ & $20.66 \%$ & $16.53 \%$ & $36.36 \%$ \\
\hline - Likely & $19.01 \%$ & $29.75 \%$ & $17.36 \%$ & $28.10 \%$ & $19.83 \%$ & $32.23 \%$ & $29.75 \%$ & $21.49 \%$ \\
\hline Unsure & $14.88 \%$ & $20.66 \%$ & $14.88 \%$ & $20.66 \%$ & $14.88 \%$ & $13.22 \%$ & $15.70 \%$ & $19.83 \%$ \\
\hline - Unlikely & $16.53 \%$ & $27.27 \%$ & $42.15 \%$ & $25.62 \%$ & $17.36 \%$ & $19.83 \%$ & $20.66 \%$ & $9.92 \%$ \\
\hline - Very Unlikely & $7.44 \%$ & $4.96 \%$ & $18.18 \%$ & $8.26 \%$ & $15.70 \%$ & $14.05 \%$ & $17.36 \%$ & $12.40 \%$ \\
\hline
\end{tabular}

Figure 5: Perceived Risks Reduction Strategies and Purchase Likelihood 


\section{CONCLUSION}

The study was undertaken with the main objective of investigating the risk perception management strategies adopted by online firms in Ghana. To this end, the study sampled 130 respondents who were workers and customers of 13 online firms operating in the Greater Accra Region of Ghana to give their opinions on the issues under study. The study concludes that the Ghanaian e-commerce industry especially the customer base, is predominantly male dominated. Most players are also young and well educated. This may be explained to mean that men and educated people prefer quicker and easier shopping methods hence their dominance on the online business sector [16]. There is however, a paucity of IT literacy among online business customers in Ghana, and customers seem to have very shortterm experiences with online shopping. The study revealed that perceived financial, social and performance risks drastically reduces the likelihood that a consumer will purchase goods offered by an online firm. The study also investigated other touching issues on the various other demographic characteristics such as a customers' age, level of education, IT literacy and exposure to online shopping all significantly affects the various risk perceptions of a client and hence their purchase decisions differ. For instance, whiles younger customers may be less worried about their financial risk exposure, older customers are worried about this and more. Additionally, the study concludes that perceived financial, social and performance risks drastically reduces the likelihood that a consumer will purchase goods offered by an online firm. However, the adoption of such strategies as brand image building, pre-purchase assistance, and awareness creation are effective in reducing customer risk perceptions and are effectively used by some online firms in Ghana. However, these are not very commonly used and the most commonly used strategies, such as quality assurance and consumer friendly website usage as well as the use of secure applications and serves do not effectively reduce consumer risk perceptions and are not very effectively used by Ghanaian online firms. Similar results were found in Vos et al, [17]. Moreover, they have very little effect on the purchase decisions of online business customers.

\section{ACKNOWLEDGMENTS}

The authors would like to say a special thank you to the Editor and all the anonymous reviewers for their invaluable comments and feedback.

\section{REFERENCES}

[1] U.S. Department of Commerce. (2000). "Digital Economy 2000." Downloaded from http://www.esa.doc.gov/de2k.html.

[2] Forsythe, S. M. and B. Shi (2003). "Consumer patronage and risk perceptions in internet shopping", Journal of Business Research, Vol. 56: 867-875.

[3] Karagozoglu, N. and M. Undell (2004). "Electronic commerce strategy, operations, and performance in small and medium-sized enterprises". Journal of Small Business and Enterprise Development, 11 (3):290-301.

[4] Shai, B.C., M. Chen, A.D. Ramdansyah and S. Wang (2015). "Comparison of decision making in adopting ecommerce between Indonesia and Chinese Taipei (Case Study in Jakarta and Taipei City)". American Journal of Industrial and Business Management, 2015, 5, 748-768.
[5] Eeden, S., S. Viviers and D. Venter (2003). "A comparative study of selected problems encountered by small businesses in the Nelson Mandeta, Cape Town and Egoli Metropoles". Management Dynamics, 12(3):13-23.

[6] Kelly, E.P. and G.S. Erickson (2004). "Legal and privacy issues surrounding customer databases and e-merchant bankruptcies: reflections on Toysmartcom". Industrial Management \& Data Systems, 104(3):209-217.

[7] Horrigan, J. B. (2008). "Online Shopping: Convenient but risky", at http://pewresearch.org/pubs/733/onlineshopping, downloaded, June, 2017.

[8] Maziriri, E.T. and T. Chuchu (2017). "The conception of consumer perceived risk towards online purchases of apparel and an idiosyncratic scrutiny of perceived social risk: a review of literature". International Review of Management and Marketing, Vol. 7 (3), 257-265.

[9] Gupta, P. and A. Dubey (2016). "E-Commerce-Study of privacy, trust, and security from consumer perspective". International Journal of Computer Science and Information Technology, Vol. 5(6), 224-232.

[10] Schurr, P.H. and J.L. Ozanne (1985). "Influences on exchange processes: buyers' preconceptions of a seller's trustworthiness and bargaining toughness". Journal of Consumer Research, Vol. 11 No. 4, pp. 939-53.

[11] Chellappa, R.K. (2001). "The role of perceived privacy and perceived security in the development of trust in electronic commerce transactions", ebizlab working paper, Marshall School of Business, University of South California, Los Angeles, CA.

[12] Yazdanifard, R. and N.A. Edres (2011). "Security and Privacy Issues as a Potential Risk for Further Ecommerce Development". International Conference on Information Communication and Management - IPCSIT Vol.16

[13] Dai, B., S. Forsythe and W. Kwon (2014). "The impact of online shopping experience on risk perceptions and online purchase intentions: does product category matter?". Journal of Electronic Commerce Research, Vol. 15, NO 1, pp. 13-24.

[14] Stewart, J. (1994). "The psychology of decision making. In: D. Jennings and S. Wattam, eds. Decision Making: An Integrated Approach". London: Pitman

[15] Chukuemwka, E.E.O. (2006). Research Methods and Thesis Writing: A Multidisciplinary Approach, Enugu: HRV Publishers.

[16] Brown, M., N. Pope and K. Voges (2003). "Buying or Browsing? An Exploration of Shopping Orientations and Online Purchase Intention". European Journal of Marketing, Vol. 37, No. 11/12: 1666-1685.

[17] Vos, A., C. Marinagi, P. Trivellas and N. Eberhagen (2014). "Risk Reduction Strategies in Online Shopping: E-trust Perspective". Procedia - Social and Behavioral Sciences 147 (2014) $418-423$. 